\title{
Australian Muslim civil society organisations: Pathways to social inclusion
}

\section{Dr Nora Amath}

Griffith University

\begin{abstract}
There is great interest on issues related to Muslims and Islam; however, a large concentration of the scholarly literature as well as media and political discourses focus predominantly on political issues and actions related to fundamentalism, radicalisation, militancy and terrorism. The dominance of these issues in the discourses does not provide a holistic understanding of Muslims, particularly their role, place and identity as minorities in a Western society. Indeed, we know relatively little about the larger number of Muslim political actors engaged in civil society, especially those involved in creating pathways to social inclusion. Utilising descriptive phenomenology, this paper explores the complex issues of social inclusion and the Australian Muslim communities. Underpinning this discussion is the theory of social capital; as noted by a number of scholars and social policy experts, the theory of social inclusion alone is inadequate and ineffective in creating participation, equality and cohesion. This paper also observes that while many reports and studies provide pragmatic suggestions on how to work towards the social inclusion of Australian Muslims, the concentration on these suggestions tend to focus on how the government can provide these solutions. What is lacking in the literature is the recognition of the Australian Muslim community's role and agency in initiating and executing the programs needed to address such issues of social exclusion. The 30 unstructured phenomenological interviews demonstrate that Australian MCSOs are proactively engaging with their communities to ensure that they are responding appropriately to these issues. Moreover, they are creating
\end{abstract}


pathways and access for Australian Muslims to better participate, engage in and contribute to mainstream society. In particular, the MCSO actors revealed four themes related to social inclusion: supporting participation in education and training, facilitating participation in employment and in voluntary work, connecting community with other people and resources, and assisting with advocacy. Although the themes are clearly in line with the Australian Government's Social Inclusion Policy, the Australian MCSOs insisted that it was not the government which set their agenda necessarily; rather, it was motivated by their faith.

Keywords: Social inclusion, social exclusion, Muslim civil society organisations, Australia, Islam, pathways

\section{Introduction}

There is great interest on issues related to Muslims and Islam; however, a large concentration of the scholarly literature as well as media and political discourses focus predominantly on political issues and actors related to fundamentalism, radicalisation, militancy and terrorism. The dominance of these issues in the discourses does not provide a holistic understanding of Muslims, particularly their role, place and identity as minorities in a Western society. Indeed, we know relatively little about the larger number of Muslim political actors engaged in civil society, especially those involved in creating pathways to social inclusion. Before any discussion on social inclusion can occur, however, it is important to outline a key concept which underpins it, that is social capital, and locate it within the discussion of how Australian MCSOs have generated and utilised it for social inclusion purposes. As noted by a number of scholars and social policy experts, the theory of social inclusion alone is inadequate and ineffective in creating participation, equality and cohesion. Bollard (2009) and others argue that it needs to be combined with the theory of social capital; otherwise, social inclusion would risk following "a path of ideology, rather than one based on empirical evaluation" (Bollard, 2009, p. 16). It is also suggested that the combination of these two theories provide a deeper understanding of what is needed for a more inclusive and cohesive society. Accordingly, this paper attempts to define what social capital means in the context of 
actors involved in Muslim civil society organisations in Australia and how this extends into and creates opportunities for social inclusion.

\section{Social capital}

The notion of social capital has been around for decades ${ }^{1}$. While there are numerous definitions and interpretations of social capital put forth by many social scientists, there are three main theorists credited with developing a deeper understanding of this concept: Pierre Bourdieu, James Coleman, and Robert Putnam.

Bourdieu (1983) differentiates between economic, cultural and social capital; he specifically understands social capital within a Marxist framework as "the aggregate of the actual or potential resources which are linked to possession of a durable network of more or less institutionalised relationships of mutual acquaintance and recognition" (p. 249). For him, it is important to understand the processes involved in resource allocation and class formation, and in doing so it allows one to understand how social capital is generally controlled by the powerful elites in society. This understanding of social capital appears to be cyclical, that is, the powerful have interactions with other powerful connections and are able to maintain their privilege and control society's resources in this manner.

Coleman (1994) approaches the notion of social capital from a rational choice theory and argues that social capital must be "defined by its function" and not as a "single entity" (p. 302). He further states that the different entities of social capital "all consist of some aspect of a social structure, and they facilitate certain actions of individuals who are within the structure" (1994, p. 302). In contrast to Bourdieu, Coleman contends that even the marginalised and disadvantaged are able to participate in this process and can possess social capital through different social structures and institutions. However, a number of critics, including Field (2003) observed that Coleman's treatment of social capital was "naively optimistic" (p. 28).

With these insights and debates in the background, Harvard political scientist Robert Putnam offers another view of social capital. Drawing on Tocqueville's commentaries on civic engagement, Bourdieu's emphasis on interaction and Coleman's focus on trust and shared norms, Putnam situates social capital within the understanding of community and association. He conceptualises social capital in this

'Lyda Judson Hanifan (1916) is credited to be the first to use the actual term social capital to discuss school community centres in rural areas. According to Smith (2009), "Hanifan was particularly concerned with the cultivation of good will, fellowship, sympathy and social intercourse among those that 'make up a social unit"'. 
manner as "connections among individuals - social networks and the norms of reciprocity and trustworthiness that arise from them" (Putnam, 2000, p. 19). He also observes that it is aligned with what many would refer to as "civic virtue" (p. 19). He warns, however that "the difference is that 'social capital' calls attention to the fact that civic virtue is most powerful when embedded in a sense network of reciprocal social relations. A society of many virtuous but isolated individuals is not necessarily rich in social capital" (p. 19).

A number of theorists concerned with social capital acknowledge that while there were a number of contributions made to provide definitions, characteristics as well as its role in society, not much effort has been made to differentiate between the different types of social capital before Putnam's attempt (see for example Woolcock, 2001 and Smith, 2009). Putnam mainly distinguishes between two main elements of social capital: bonding and bridging.

Similar to the Marxian/Weberian conception of bounded solidarity (see Lou Wilson, 2006) and the Durkheimian notion of mechanical solidarity, bonding social capital involves creating associations between homogenous people or groups. Putnam (2000) refers to this as "exclusive" and "inward looking" and argues that this type of capital allows for harnessing trust, reciprocity and "mobilising solidarity" ( $p$. 22). Examples of bonding social capital would be an ethnic or cultural group, a church-based playgroup, or a young women's library reading group.

For Putnam (2000) bridging social capital is "inclusive" as well as "outward looking" and involves the linking of connections between heterogeneous groups. This is similar to the organic solidarity as conceived by Durkheim. It is through this type of social capital that Putnam contends will create critical associations with external links and networks; in turn, these associations offer better opportunities for social inclusion as well as act "as source(s) of social cohesion in the Durkeimian sense" (Wilson, 2006, p. 350).

While Putnam distinguishes only between bonding and bridging capital, other commentators (such as Woolcock, 2001) concerned with social capital include a third form- linking. Linking goes beyond bridging and provides opportunities for people or groups to make better connections and gain more leverage with institutions or systems outside of bonding or bridging capitals for the much needed resources. In order for a community to flourish appropriately or what Alison Gilchrist (2009) refers to as the "well-connected community", all three types of social capital is 
necessary (see also Furbey et al., 2006 and Furbey, 2007; Jochum, Pratten, \& Wilding, 2005).

\section{Social inclusion}

Like other concepts in the social sciences, there are a myriad of definitions posited for social inclusion. One such example is the United Nations' (2014) working definition which defines social inclusion as:

the process by which efforts are made to ensure equal opportunities - that everyone, regardless of their background, can achieve their full potential in life. Such efforts include policies and actions that promote equal access to (public) services as well as enable citizen's participation in the decisionmaking processes that affect their lives. (para 5

The UN also highlights that social inclusion is closely aligned with other concepts such as social integration whereby all members of society (which are not necessarily homogenous) are able to fully belong, participate and are included in all aspects of society.

The concept of social inclusion originates from France in the 1970s, but it only became public social policy when the European Union (EU) reified the robust discussions on how to combat poverty, disadvantage and marginalisation in the 1980s and 1990s. It gained traction in Australia, when the former Premier of South Australia, the Honourable Mike Rann, created the Social Inclusion Initiative (Hayes, Gray, \& Edward, 2008) to address issues of social and economic deprivation and marginalisation. Other states and territories in Australia adopted similar social inclusion frameworks and policies in the subsequent years. A nationwide initiative was finally created by the Labor Government, under the leadership of the then Prime Minister, the Honourable Kevin Rudd; it was considered to be one of the major priorities for the country at the 2020 Summit $^{2}$. The national Social Inclusion Agenda was presided by the Deputy Prime Minister at that time, the Honourable Julia Gillard, who stated that the aim was a long-term focus at "creating prosperity with fairness" (Gillard, 2008). It has since been renamed the Social Inclusion Policy by the present Government.

\footnotetext{
${ }^{2}$ As the Social Inclusion Agenda website has been dismantled by the present Liberal Government, a detailed discussion of this can be found in Hayes et al. (2008) Social Inclusion: Origins, Concepts and Key Themes, Canberra: Australian Government. The report can be retrieved here: http://homelessness.energetica.com.au/dmdocuments/aifssocialinclusionreportoct2009.pdf
} 
Another term parallel to social inclusion is social exclusion; in fact, a thorough literature search yields more discussions on social exclusion than social inclusion. It is often argued by many that it is imperative to understand the processes involved in exclusion before we can address issues to facilitate the processes of social inclusion (see Taket, Crisp, Nevill, Lamaro, Graham, \& Barter-Godfrey, 2009). The process of social exclusion is generally accepted to be multidimensional and such excluding factors may include poverty, education, age, gender, health/disabilities, location and housing issues. However, many scholars and social and public policy commentators contend that understanding social exclusion only from these factors is limiting (Fraser, 1997; Lister, 2002). At the beginning of the social inclusion movement globally, Fraser (1997) argues that the "struggle for recognition is fast becoming the paradigmatic form of political conflict in the late twentieth century" (p. 11). Radical democracy proponents agree with Fraser and insist that besides socio-economic inequality, there are other aspects of inequality which can have an exclusionary impact on people, such as race, religion and sexuality (Lister, 2002).

There are three popular approaches to understanding social inclusion/social exclusion as proposed by Levitas (1998); they are: SID, which refers to the social integrationist discourse and is popular in the United Kingdom and the European Union; MUD, which is the moralistic discourse referring to the underclass, individual behaviour and values; and, finally, RED which articulates a redistributive, egalitarian discourse with notions of citizenship, social rights and social justice. Whichever approaches a national, state or local agency utilises, a general way of understanding social inclusion is to understand it in very utopian terms, that is of processes whereby those who are marginalised, excluded or denied in society have opportunities to be fully participating, integrated and valued citizens (Mansouri \& Lobo, 2011).

The literature on social inclusion and Muslims in the Australian milieu mainly appears to be contextualised within the discussions of multiculturalism and citizenship (Department of the Prime Minister and the Cabinet, 2010; Mansouri \& Lobo, 2011; Yasmeen, 2010). One of the major reports on social inclusion and Australian Muslims is the report by the Department of Foreign Affairs and Trade (2008) entitled, Engaging with Australia's Muslim Communities. It details the Government's official stance on engaging with Australian Muslims and on encouraging the dialogue between Muslims and non-Muslims in Australia. The 
website also highlights the National Action Plan which aims to foster "social cohesion" and "harmony" as well as "addressing isolation and marginalisation." In particular, the report recommends and emphasises an engagement with Australian Muslim youth through Muslim civil society organisations. A number of other government reports and studies notably focus on issues related to Australian Muslim youth and social inclusion. For instance, Noble and Poynting's (2010) study explore the "racial vilification" of young Arab and Australian Muslims in the context of social inclusion, belonging and citizenship. The authors interviewed 186 participants and found a significant number of respondents faced exclusion based on "every-day racism" that is the smaller, often unnoticed, racism in Australian society. They note that as a result of this, public use of space can be used to identify and mark who is included and excluded, such as the Cronulla riots.

It is noteworthy that the concentration of the literature is on government policies, discourses and rhetoric which may appear to be exclusionary, especially policies related to refugees and asylum seekers and issues related to security post9/11 (Vertigans, 2010). This can be problematic and limiting as Muslims "are constantly made aware of the conditionality of their citizenship" (Humphrey, 2010, p. 56). Thus, the social exclusion and inclusion of Muslims is not a simple nor straightforward process. Rather, it is multidimensional, complex and intersects a number of different variables; it involves not only the social and economic processes, but also demands a refocus on the social and political policing and securitising measures by the state which concentrates on ensuring that socially excluded Muslims are managed so that they do not disrupt or harm the state.

The literature also features numerous reports and studies providing pragmatic suggestions on how to work towards the social inclusion of Australian Muslims. The concentration on these suggestions tends to focus on how the government can provide these solutions (Department of Foreign Affairs and Trade, 2008; Department of the Prime Minister and the Cabinet, 2010; Hassan, 2010). What is noticeably lacking in the literature is the recognition of the Australian Muslim community's role and agency in initiating and executing the programs needed to address such issues of social exclusion (McCue, 2008 is an exception). This is an important area of research which needs sufficient investigation and discussion in order to better inform researchers, community developers and policy makers in their understanding of social inclusion/exclusion, engagement and agency at the local level. 


\section{Research approach}

Utilising descriptive phenomenology as the research approach, this study is focused on exploring and understanding the complex issues of social inclusion and Australian MCSOs. Michael Harmon (1990) notes that phenomenology allows for a more effective understanding of organisations and, accordingly, makes two observations. Firstly, through phenomenology one is able to understand what has been done as a result of the action being completed. Secondly, as actors involved in the organisations may differ as to what should or what is actually going on, phenomenology allows for a constant, cooperative collaboration. Thus, Harmon (1990) concludes that the study of organisations with a phenomenological attitude "is a process of collective sense-making about what people have been doing, what they might want to do in the future, including (but not limited to) how they might want to do it" (p. 11). One of the primary ways in which a researcher studies communities, organisations or institutions is through the people involved- the actors (Seidman, 2006).

The complexities involved in capturing the actor's lived experience of the phenomena can only be revealed through one-to-one interactions, between the researcher and the participant. It must not be a simple conversation, but rather a deep, reflective dialogue which, according to Husserl (1970b), must involve attentive listening, interaction and observation by the researcher.

\section{Participants}

Unlike quantitative or experimental research where hypotheses are being tested or situations controlled, applied descriptive phenomenological research involves obtaining deep, reflective lived experiences from the participants and uncovering the 'essences', that is, the thematic patterns, of those experiences. Because the research approaches are quite different, selecting participants to sample had to be approached differently. While it was necessary for this study to select participants whose experience "would not be easily dismissed as idiosyncratic to them and irrelevant to a larger population" (Seidman, 2006, p. 51), it could not employ random sampling or stratified random-sampling. As a result, 15 participants were sampled purposively, based on their qualities, experience and relevance to the research; each participant was interviewed twice. There were six participants from NSW, six from Victoria and three from Queensland. In total, 30 face-to-face, in-depth interviews 
were conducted. Table 1 details the 15 Australian MCSO actors, their position title and the organisations they represent in the three cities: Brisbane, Sydney and Melbourne.

Table 1

Participant Details

\begin{tabular}{|c|c|c|}
\hline Participant Name & Title & Organisation \\
\hline Mustafa Ally & Founder and President & $\begin{array}{l}\text { Crescents of Brisbane } \\
(\mathrm{CoB})\end{array}$ \\
\hline Galila Abdel-Salam & Founder and Manager & $\begin{array}{l}\text { Islamic Women's } \\
\text { Association of Queensland } \\
\text { (IWAQ) }\end{array}$ \\
\hline Salam El-Merebi & Founder & Al-Nisa Youth Group \\
\hline Saara Sabbagh & Founder and President & Benevolence Australia \\
\hline Tasneem Chopra & Chairperson & $\begin{array}{l}\text { Australian Muslim } \\
\text { Women's Centre for } \\
\text { Human Rights (AMWCH) }\end{array}$ \\
\hline Sabah Hakim & Founder and President & Australian MADE \\
\hline Omer Atilla & Executive Advisor & $\begin{array}{ll}\text { Australian } & \text { Intercultural } \\
\text { Society (AIS) } & \end{array}$ \\
\hline Kerim Buday & President & $\begin{array}{l}\text { Australian Social Islamic } \\
\text { Association (ASIA) Youth }\end{array}$ \\
\hline Zeynep Sertel & Founder and President & Sareera \\
\hline Zia Ahmed & President & $\begin{array}{l}\text { Islamic Foundation for } \\
\text { Education and Welfare } \\
\text { (IFEW) }\end{array}$ \\
\hline Hanan Dover & Founder & Mission of Hope $(\mathrm{MoH})$ \\
\hline Zubeda Raihman & Treasurer & $\begin{array}{l}\text { Muslim Women's National } \\
\text { Network of Australia } \\
\text { (MWNNA) }\end{array}$ \\
\hline Maha Abdo & Executive Officer & $\begin{array}{l}\text { United Muslim Women's } \\
\text { Association (MWA) }\end{array}$ \\
\hline
\end{tabular}




\begin{tabular}{|l|l|l|}
\hline Kuranda Seyit & Founder and Director & $\begin{array}{l}\text { Forum on Australia's } \\
\text { Islamic Relations (FAIR) }\end{array}$ \\
\hline Elias Attia & Public Officer & $\begin{array}{l}\text { Islamic Society of UNSW } \\
\text { (ISOC) }\end{array}$ \\
\hline
\end{tabular}

\section{Ethical considerations: Role of the researcher}

I am a Muslim who is very active in the Muslim community in Brisbane, having founded and chaired several MCSOs in the last decade. Having sat on several Muslim reference groups, I also have an extensive contact base with other key Muslim leaders throughout Australia which assisted in soliciting participants for the study. I believe that my identity as 'one of them', that is as a Muslim and an Australian MCSO actor, facilitated and provided a smooth dialogue with my participants. My reflexivity, in this case, proved beneficial and effective. Wittner (1998) also notes this and states that "contributors who were members of the group they studied....were able to offer more information than we would know otherwise" ( $p$. 380). Furthermore, unlike other researchers who encountered suspicion, mistrust or hostility, I was, instead, embraced, supported and provided with very deep, personal reflections.

\section{Procedure}

The unstructured, in-depth phenomenological interviews were conducted at a place of the participant's choosing to allow for maximum ease and comfort for the participants. The two separate interviews were conducted with each participant, consisting of at least one and a half hour each, over a series of two to three weeks; this accounted for internal consistency as well as idiosyncratic days. Each interview was tape-recorded and then transcribed verbatim, and notes were also taken during the interview.

While there are a number of different approaches to conducting applied descriptive phenomenological research, most researchers agree on a few key procedures: bracketing, analysing and describing (Giorgi, 1997; Moustakas 1994; van Manen 1990; Wojnar \& Swanson, 2007). Bracketing is a major tenet of phenomenological research and involves what Husserl (1970b, 1980, 2001) calls "transcendental subjectivity" or the "epoch" wherein the researcher "holds in 
abeyance any preconceived ideas while he or she is listening to, interacting with, and analysing the stories of the participants" (Wojnar \& Swanson, 2007, p. 173).

The second component of the descriptive phenomenological inquiry involves analysing the interviews which have been transcribed verbatim; this process is also referred to by many as the process of explication. There are a number of guidelines offered by Colaizzi (1978), Moustakas (1994), and Amath (2014) including the rereading of texts a number of times, extracting significant statements, categorising these statements into meaning units and finally, clustering these units into subthemes. Describing is the final process in phenomenological research inquiry and involves the researcher identifying the themes common to most or all of the interviews, from the derived sub-themes and meaning units. Here, a textual description of the participants' experiences is provided along with the structural description which details how they experienced the phenomena according to the situation, conditions and contexts (Creswell, 2007; Moustakas, 1994). Describing also involves researchers taking note of the individual variations.

\section{Results}

The phenomenological interviews with the Australian MCSO actors revealed four themes related to social inclusion: supporting the participation in education and training, facilitating participation in employment and in voluntary work, connecting community with other people and resources, and assisting with advocacy.

\section{Theme 1- 'empower...through education and capacity building': Supporting the participation in education and training}

One of the main themes related to the social inclusion process involved Australian MCSOs creating pathways and facilitating participation in education and training. Omer Atilla from the Australian Intercultural Society (AIS) explained that one of their organisation's main goals was to 'establish education facilities (so that they) become educated people who are beneficial to the society they are living in.' Representative of the Muslim Women's National Network of Australia (MWNNA), Zubeda Raihman, highlighted that the majority of their programs specifically revolved around capacity building. She stated, 'We have leadership building...empower woman through education and capacity building.' Raihman elaborated further on such programs: 
We ask our grassroots organisations to send their representatives and it's mostly free because (of) government grants and they come and attend this sort of training program. It's hands-on training; it's very well run. It used to be run by our sister organisation in Victoria and they have special offices and are highly qualified in that area. (We teach them) how to budget, how to plan, how to relate, how to do interfaith, how to communicate.

Maha Abdo from the United Muslim Women's Association (MWA) stated that their organisation was primarily established to assist Australian Muslim women better participate in education and training. Abdo explained, 'Our target group is Muslim women, because Muslim women don't have those facilities or the space to go anywhere else.' She further outlined:

We educate, we train, skill them up and now they (clients) are working at various government and non-government organisations at a local, state and national level. We encourage further education. We have a lot of young women who started off with us as young people at our spiritual retreats and we mentored (them) throughout the years, and (the) mentoring programs have been running throughout the organisation for 21 years.

Salam El-Merebi stated that through their programs, the Al-Nisa Youth Group is able to 'provide the public with education, especially the young Muslim women on parenting skills, leadership skills.' In particular, Al-Nisa wanted to build and enhance the leadership capacity of their young committee members. Mustafa Ally stated that Crescents of Brisbane ( $\mathrm{CoB})$ also provided opportunities for their young members to build leadership skills. He explained:

The idea was to give them some scope for event management and conducting meetings. For example at our meetings there is a rotating chairperson, and we try to make sure all the youngsters chair the meetings so they get a feel for what it is to run the meeting.

Zeynep Sertel from Sareera concurred and said that the organisation she helped founded and chairs focused on building 'self-esteem, leadership skills ...communicative skills and media skills as well.' Sertel expounded on the focus on 
leadership training: 'developing leaders for the future, we take a holistic approach. They understand their body, their soul, their responsibilities, for their community so they can be better citizens who help the development of community.'

Hanan Dover spoke specifically about the Hayat Program, one of Mission of Hope's $(\mathrm{MoH})$ initiatives to assist those vulnerable youth on the street. In particular, she discussed how important it was to ensure that the volunteers who engaged in this type of work were fully educated and trained appropriately so that they would be able to respond effectively.

It is interesting to note that a number of the Australian MCSO actors interviewed referred to their religion, Islam, as being a source of social inclusion demands, especially in regards to education. Sertel discussed: 'It's a combination of things but the main drive behind that, in my opinion is, I think, Islam...one of the principles in Islam is that you are part of the community.' She further elaborated that assisting with the social inclusion process for their organisation is viewed 'as a religious duty as well as a community duty.' Atilla concurred and reflected: 'I think you can say the main inspiration was Islam, the main reason for that.'

Abdel-Salam from IWAQ spoke specifically about Islam's view on the inclusion of women in society:... the interpretation of women and men in society in the Muslim community is different than what is Islam, and the interpretation of equality is taken wrongly.

Zia Ahmed from the Islamic Foundation for Education and Welfare (IFEW) stated that their organisation stressed on 'the equality of genders.' He elaborated that 'from the very beginning, IFEW has encouraged female leadership, as a matter of fact most of the time IFEW leadership was female.' Like Abdel-Salam, Ahmed stated that his organisation's feminist view stemmed from their sacred text, the Holy Quran:

'From an Islamic point of view, men and women are equal, mentioned in the Quran clearly and I think it was lot of cultural and historical practices which had made this looking down on women, inequality and oppression things like that acceptable.' 


\section{Theme 2- 'they have skilled up and furthered their education but they are still in senior positions in the organisations': Facilitating participation in employment and in voluntary work}

Another theme related to the social inclusion process involves Australian MCSOs facilitating client, members and community participation in employment and voluntary work. Abdo commented about some of their past clients and stated, 'They have skilled up and furthered their education but they are still in senior positions in the organisations and we have young women that will continue to come and do a lot of volunteering; we provide volunteering programs.' She also discussed about one of their social enterprise projects to assist in obtaining paid employment and said:

We have a program where older women, utilising their sewing skills that they learnt through the organisation, make handbags out of recycled material. And then we set them up in a social enterprise, and hopefully that will take them up; they are actually selling the handbags in markets.

Abdo revealed that one of the reasons why they established the MWA was to provide Muslim women with employment opportunities. She stated:

I think in a nutshell the Muslim Women's Association is to cater for Muslim women in Australia, by Muslim women in Australia with the aim of creating a safe, secure, trusted space to practise and implement our Islamic-Australian identity, which involves every aspect of education, training, employment, social issues of concern as new arrivals come to the country.

Abdel-Salam also highlighted this aspect of social inclusion and impressed that that they wanted an organisation 'which can be run by Muslim women to identify a woman's need and create opportunity for Muslim women to work.' Moreover, another important factor in the social inclusion process Abdel-Salam discussed was providing flexible working hours for people, especially Muslim women with children. IWAQ recognised that it was vital to meet this need so that people can still participate and integrate fully in society. Besides providing flexible working hours, the organisation is keen to provide onsite childcare, not only for its workers but for the community. 
Beyond providing internal employment for just the organisation alone, one of their major goals is to help the community get the necessary education, training and skills to ensure that they are able to readily enter other areas of the work force. Abdel-Salam highlighted:

the major issue was to recruit workers, train them and get them a job with a client...we have training opportunities. We have that team of people who need training from literacy issue and English to Certificate III because some of them are interested in working but have no qualification at all.

Abdel-Salam concluded that IWAQ has been a stepping stone for many Muslim women in the community to be able to confidently gain employment in mainstream organisations. She stated:

Through the years I can easily say hundreds of Muslim women who worked with us to get experience, to get the confidence, were able to move to other organisations. So we are still an indirect way to mainstream organisations and other service providers that Muslim woman cannot only access.

Sertel agreed and said that their organisation wanted to 'equip them with the skills that they will need to have to volunteer and contribute to society.' El-Merebi also discussed how the Al-Nisa Youth Group trained their volunteers and linked with other organisations, such as Volunteer Queensland, to be able to deliver the services.

\section{Theme 3- 'we bring in our expertise from outside': Connecting community with other people and resources}

A third theme related to social inclusion involves Australian MCSOs assisting the community in connecting with other people, groups and resources. For example, Abdel-Salam stated that one of IWAQ's main goals was to connect the community with much-needed resources. In particular, one of the major needs in the community was to provide appropriate age care and respite facilities. With this knowledge, IWAQ applied for government funding to meet the community's needs and set up the first Muslim aged and respite care in Queensland. 
Through MoH, Dover discussed how they were able to connect local Muslim women to much needed resources. She stated, 'We used to have for about six years, swimming programs, teaching women how to swim. That support is given now to the Department of Sports and Recreation.' She stressed that $\mathrm{MoH}$ encouraged obtaining training and expertise from outside to enable for more effective delivery. She articulated:

We get our awareness, understandings, education and information, knowledge from outside Mission of Hope and we bring it into Mission of Hope. So that's how we do our things, we don't just rely on our own knowledge. It's not as if we have a strict framework from which we operate so we are bring in our expertise from outside into Mission of Hope.

Abdo observed that MWA also responded to the community's needs to connect with necessary resources so that they could become more socially integrated. She stated:

A lot of women have said they want to learn how to drive, so that is something that we are now putting together with the local council and providing them with an instructor. And we have someone here who can help them with the process and these are women who have mainly been in isolation or don't have any other support in the community.

Abdo also spoke about the importance of connecting with other people in the community. One of their key initiatives to facilitate better social inclusion for the community involves mentoring. She elaborated on the concept:

Mentoring is part of the Islamic tradition and we did that (through MWA), because when I was growing up I didn't have a mentor. And so we began with the question- how do you provide mentoring to young women? You don't just go let's be, I will be your mentor you become my mentee. But Islamic traditions provide that in a very relaxed non-invasive way where you don't dictate to the other person what they should and shouldn't do.

In addition to connecting the community to much needed resources and services, Hakim from Australia MADE discussed the importance of connecting 
people to each other and seeking advice from others. She noted: 'we had actually contacted the law firm in Dandenong (Victoria) and got them on board for some free advice to invest and expand and we had contacted different employment agencies for reskilling courses.'

El-Merebi also stressed that it was important that Al-Nisa provided the necessary training and expertise for their volunteers, including obtaining that training from outside of their organisation. She stated, 'So we do go out and work with nonMuslim organisations to get ourselves also educated and trained before we deliver it to the community.' El-Merebi then explained that this relationship with other organisations, especially non-Muslim organisations, translated into creating links and connections with their own members, clients and the wider community and observed:

We did get a lot of contacts and with the youth workers at the time part of their job was to go out and get themselves known by non-Muslim organisations and present themselves to non-Muslim organisations to be able to work with them on youth issues.

Similarly, Sabbagh from Benevolence Australia stated:

(We) work closely with local council and...they know us quite well, they turn to us for any programs they might need assistance on, particularly the Muslim community. So we try to get out there as much as we can. Federal police, local police also are aware of us, we work with them closely in the issues they may have with Muslim families, teenagers, drugs abuse they call on us.

Buday from the Australian Islamic Social Association (AISA) Youth discussed how their organisation worked with the local mosque and local community centre to assist their members and others in the community. He elaborated:

We have an alliance with the Meadow Heights Learning Shop which is right across Meadow Heights Mosque. It's really like a community centre open to the wider community there, and we have been to their open day and presented and formed a few alliances there. If there is anything that the mosque can do to contribute or assist with the local community we have got bonds there. What we have encouraged is members from our community who 
might be facing things such as language difficulties to go to their learning centre and attend their courses.

Buday fondly shared a story from one of the connections and related: 'one thing that we had out of that was the ex-Sheik or imam of Meadow Heights mosque who passed away this year, was learning English at their learning centre at 65, and that was something that was amazing at that age- you had the Imam go across the road to learn English.'

\section{Theme 4- 'to have a voice, a voice within the community': Assisting with advocacy}

A final theme related to the social inclusion process revolves around Australian MCSOs assisting their clients, members and the community with advocacy. Raihman discussed the MWNNA's role in providing advocacy and training women to be their own advocates. She explained that 'it's about empowering women, Muslim women and it's about educating them.' She also stated that their organisation wanted to assist 'Muslim women (in) making a difference in the community. And how are they are making a difference? They are making a difference by using knowledge- so knowledge is power. That's our main area of emphasis.' Raihman further stressed:

Part of the women's network was advising them (their members and clients) on what the government has in store and representing the women to the government....the organisation is a voice for women. We have one project we called it "Shout" and you can see it on our webpage. It's a voice for women. We are trying to educate and mentor women, young women. It's a project for young women to have a voice, a voice within the community, to fight the negatives.

Abdel-Salam also explained that one of her roles as manager of IWAQ involved advocating on behalf of Muslim women. She contended:

I have to go and talk to other workers and other organisations about Muslim women especially when they go to the refuge (domestic violence). And I was like Muslim women have strict food issues, religious issues, cultural issues. They (Muslim women) feel discriminated there; they are abused by other 
women in the refuge. A woman who is a victim can be a bully, especially by other woman Australian woman.

Dover discussed how the Justice and Arts Network (JAAN), a branch of $\mathrm{MoH}$, is a safe place 'where young people can get together creatively and discuss social justice issues and creative expression.' According to the JAAN website, that:

Based on the premise that given a voice, the youth must and will feel empowered and confident in their ability be part of the solution, all towards benefiting them as individuals and towards the community as a whole. JAAN also aims 'to develop, establish and promote a wide range of essential and innovative grassroots activities and services to address the needs, rights and entitlements that are designed to get people involved in creating a community that is socially, economically and environmentally sustainable.

A major issue facing the Australian Muslim community relates to terrorism and counter-terrorism. As a result of this, the Australian MCSOs felt that some Australian Muslim youth may feel socially excluded. Buday discussed this phenomenon and explained how ASIA Youth can assist the Muslim community in advocating on these pertinent issues. He stated:

I have spoken to people in Victoria Police and the Australian Federal Police where they talk about the anti-terrorism unit. (It) is basically the counterIslamic terrorism unit. That's what it has basically been made for, but there is not enough people of Islamic background at grassroots level who have a voice, who can actually influence what is happening in those units or when there is legislation passed. I found out there is an independent reviewer but there is only three part-time staffers on this independent review of terrorism laws.

Buday further elaborated how vital it is to ensure that the Australian Muslim community advocate effectively on these issues. He impressed:

How do you prevent these laws being inappropriate, being invasive being inadequate in general if you don't have that Muslim input? It really comes back down to being more aware and very alert. Again it's probably very broad 
and general but the aim is to help the youth growing up to become more aware of events affecting Muslims. Not only will it help them personally but if they can voice their opinions it will help the Muslim community at large go forward because the only way you stop this from happening is by making people aware of the facts or the truth or maybe some of the background information to help rectify some of the erroneous information.

The phenomenological interviews with the Australian MCSOs reveal that there are four themes related to the processes of social inclusion; they are: supporting the participation in education and training, facilitating participation in employment and in voluntary work, connecting to other people and resources, and assisting members and the community in advocacy.

\section{Description and discussion of Australian MCSOs facilitating pathways to social inclusion}

The findings demonstrate that all three forms of social capital are at play in these Australian MCSOs to enable the creation of pathways to social inclusion. Through MCSOs, Muslims are able to firstly build their bonding capital, by associating with like-minded individuals with shared interests, values, traditions, ethnicity, culture and religion. Some of the workshops and training may be conducted through instructions or conversations in the members' native language initially; through gender-specific activities; religious instructions and so forth. As a result a shared consciousness lies within the intragroup and bonding capital is built.

While remaining in this manner can lead to exclusivity as has been argued by a number of scholars concerned with social capital (see Putnam, 2000; Woolcock, 2001). The MCSOs argued that this is first needed to strengthen a person's trust, purpose and identity, allowing for their confidence-building in a secure and supported environment. This then enables the MCSOs to provide pathways beyond bonding capital; accordingly, the organisations are able to introduce connections with other diverse social groups allowing for bridging capital to manifest. The findings also revealed that Australian MCSOs also fulfil the role of providing bridging social capital by allowing their members to reach out and access other people, connections and networks. This was clearly evident when the Australian MCSO actors discussed the connections they sought intentionally to assist their members. Furbey (2007) notes, 
however, that faith-based organisations can also be obstacles of social capital and, in particular, cautions that emphasising bonding capital can result in faith-based organisations being exclusive and narrow.

Indeed, the interviews reveal that Australian MCSOs are well aware that they need to ensure that their organisation does move away from bonding, which can be narrow and exclusive, to more inclusive and outward bridging and linking aspects of social capital. For example, Sareera aims to provide opportunities and encouragement to young Muslim females with the necessary skills, knowledge and capacity to become successful leaders. In particular, the organisation's promotional brochure states that Sareera aims to "integrate academic, personal and religious skills and Australian values in order to nurture active, responsible and positive citizens to benefit the Australian community" as well as "establish a cooperative, unified and positive working relationship with the broader Australian community" (Sareera, n.d.).

Another Victorian organisation which engages widely with the broader community is Benevolence Australia. The vision of Benevolence Australia is dedicated to the worship and service of God, while acknowledging the sacredness of everything and everyone. In doing so, they wish to serve the whole of humanity. Moreover, according to their website their "aim is to create an environment where people can come together and work in partnership in creating a more respectful and compassionate Australian community". Some of the programs serving the wider community include youth camps, educational forums and workshops, community dinners, health and well-being initiatives, counselling, kinesiology, book clubs, school programs and spiritual retreats

As articulated by the actors, Australian MCSOs are highly involved and proactive in generating high levels of all forms of social capital allowing for a more inclusive and cohesive society. This is especially beneficial for Australian Muslims who feel socially excluded from mainstream Australian society. Moreover, when Australian MCSOs are able to provide the bonding, bridging and linking forms of social capital, they are then able to facilitate better pathways to social inclusion.

It is interesting to note that the Australian Government defines a social inclusive society as "one in which all Australians feel valued and have the opportunity to participate fully in our society" (Commonwealth of Australia, 2010). Accordingly, achieving this vision means that all Australians will have the resources, 
opportunities and capability to learn by participating in education and training work by participating in employment, in voluntary work and in family and caring; engage by connecting with people and using their local community's resources; and have a voice so they can influence decisions that affect them. (para. 2)

The findings from this study indicate that Australian MCSOs are providing these exact services for their clients, members and the community as a whole. When I mentioned this to one of the MCSO actors involved in this study her response was that the organisation she represents and manages, the MWA, had been engaging in and facilitating pathways for the social inclusion of Australian Muslims from the start of the organisation's establishment, which was in 1983. Abdo further explained:

Well nothing changed. They (the Australian Government) brought it (Social Inclusion Agenda) out, but we didn't initiate it. We have been doing it since day one. We did not engage in getting any of the funding for social inclusion because we said we have already been doing that.

Interesting, Abdo, like others, articulated that the motivation for developing and implementing programs to address issues of social inclusion derives from a faith basis, rather than a secular one. She argued:

Islam is for social inclusion, this is an actual fact. For the Government, it's a new thing- it's great. But for us, it is not only great, it is something that we do every day. That's where we say you have called it social inclusion we have called it partnership, collaboration. We have called it working with real people and that's what our organisation was set up for in the beginning, by and for the same people. It's encouraging other people to be involved with you and to not discriminate between this, that and the other.

Sabbagh expressed the same sentiment and reflected that assisting people through the social inclusion process was part of their organisation's 'journey to the Creator.' These remarks are echoed by the research and experiences of other Muslim civil society actors in other Western societies. For example, in Ali, Jamoul and Vali's (2012) report, A New Covenant of Virtue: Islam and Community Organising, these seasoned MCSO actors argue that "Muslim communities need to lead and participate in positive change in their societies. Muslim communities need 
to work together, deliberately and consistently finding allies and building relationships within its diverse communities and beyond" (p. 17). The authors particularly stress on the importance of harnessing social capital, that is relationship building, trust and network and contend (like Putnam, 2000) that "no community is as strong individually as it is collective" (p. 17). Moreover, they base their argument on the Quran, specifically chapter 5: verse 2 and chapter 13 , verse $11 .^{3}$ Beyond issues of social capital, Ali et al. (2012) also discuss that many of the social inclusion processes such as leadership capacity and training, volunteering and advocacy can be derived from an Islamic basis, as similarly argued by a number of Australian MCSO actors interviewed in this study.

Furthermore, recognising that Islam or external manifestations of it such as dress or even one's name can be elements of exclusion, one of the major reasons for the establishment of some Australian MCSOs, particularly the Muslim women's organisations, was to facilitate and create employment opportunities especially for Muslim women. Abdel-Salam from IWAQ made this point very clear in her interview when she stated that this was one of the reasons for their establishment, due to the fact that unfortunately, Muslim women who visibly adhere to the Islamic attire of modesty in the public sphere were often discriminated against in the employment arena. In fact, there are quite a number of Muslim women who find it difficult to obtain jobs (Human Rights and Equal Opportunity Commission, 2004; Poynting \& Mason, 2008). Nahid Kabir (2008) also reached a similar conclusion in her study of Muslims in Sydney. She contends that "some (women)...who wore the hijab found their Australian identity was questioned and they felt less connected to Australia because they felt rejected in the labour market" (p. 23). Yasmeen's (2008) study suggests several ways to bridge the divide between exclusion and inclusion, including changed government rhetoric about Muslims and Islam; a more holistic government-Muslim engagement beyond issues related to youth and women in hijabs; awareness that the social exclusion is also a racial issue, not just religious; and finally a raised-awareness regarding the diversity of Australian Muslims. She did not, however, cite the harnessing of social capital to address issues of social inclusion, unlike this study.

\footnotetext{
${ }^{3}$ Chapter 5: verse 2 in the Quran reads: "And cooperate in righteousness and piety, but do not cooperate in sin and aggression." Chapter 13, verse 11 reads: "Indeed, Allah will not change the condition of a people until they change what is in themselves."
} 
The findings also demonstrated that there is a targeted approach to the social inclusion processes by the Australian MCSOs. In particular, this study highlighted the importance of building social capital at the grassroots level before pathways to social inclusion can be addressed. Moreover, it is not governments, policy makers or wellintentioned bureaucrats taking a top-down approach, dictating what types of programs or initiatives are needed to assist people feel socially included; rather the Australian MCSOs are in touch and regularly meet with their clients, members, and the community to gauge what is needed. For instance, as a result of a consultation with the Muslim community in Sydney, it was revealed that quite a number of Muslim women felt isolated and socially excluded because they were not able to drive. The MWA immediately approached the local council; soon the necessary linguistically and culturally sensitive arrangements were made to assist the Muslim women in their learner drivers' instruction. All of the organisations included in this study advised that they all have regular consultations with the community in order to better meet the needs of the community. Similarily, Cobigo, Ouelette-Kuntz, Lysaght and Martin (2012) in wanting to better comprehend the shift in understanding the social inclusion process conducted a literature review on these issues and conclude that communitybased civil society organisations have a major role to play in this process. They contend that "a growing body of evidence demonstrates the effectiveness of community-based supports and services that are person-centered and help people assume meaningful roles and relationships in society" (p. 78).

Another issue which became apparent after consultations with not only the Australian Muslim communities but with various governmental bodies, including the New South Wales Police department was the issue of troubled youth. As a result of this targeted approach, MoH and the Lebanese Muslim Association (LMA) in Sydney launched the Hayat (Arabic word meaning life) House, to rehabilitate those addicted to drugs and alcohol in a "culturally appropriate community-based" manner. An additional issue affecting youth is education. Buday from ASIA Youth stressed that this was one area which his organisation along with other MCSOs need to help the youth with in terms of the social inclusion process. He explained:

I think a massive issue with the Muslim circle in general is education, a real lack of knowledge. We really pushed the educational front and hopefully bring that to the forefront and encourage them to be as knowledgeable as possible 
and help them with their religion which will help them with their career aspirations and just help them become more refined, well rounded individuals in general.

It is important to also note that Australian MCSOs feel that their role is to not only create a safe environment for Muslims to be socially included in society through the harnessing of social capital, but also to give a sense of ownership to those participants. The interviews revealed that this is especially true for young Muslims. For instance, El-Merebi of the Al-Nisa Youth Group explained that it was important for all the members on their management board to take turns chairing and stated, 'We want the girls to learn that process of chairing.' El-Merebi added that the experience has helped that particular committee member overcome her shyness in a safe space, allowing her to strengthen her self-esteem and boost her self-confidence which helped suitably prepare her for her future job, her roles in other organisations and enabled further connections with other networks.

\section{Conclusion}

This paper focused on how issues of social inclusion and social exclusion are addressed within the context of the Australian Muslim communities as revealed by the phenomenological interviews with Australian MCSOs. It noted that the building of all three forms of social capital, bonding, bridging and linking are first needed to be established in order to better facilitate pathways to social inclusion. Additionally, the paper expounded that while many reports and studies provide pragmatic suggestions on how to work towards the social inclusion of Australian Muslims, the concentration on these suggestions tend to focus on how the government can provide these solutions. What is lacking in the literature is the recognition of the Australian Muslim community's role in initiating and executing the programs needed to address such issues of social exclusion. Indeed, as this paper reveals Australian MCSOs are proactively engaging with their communities to ensure that they are responding to these issues.

Moreover, it is widely acknowledged that the social inclusion and exclusion processes are multidimensional, complex and intersects a number of different issues; specifically, external variables such as political or terrorist events and internal 
factors such as focused policing and securitising measures as well as debates on Australian values and sense of belonging have engendered challenges for Australian Muslims. However, despite all these challenges, it appears that MCSOs are focused on providing pathways for Australian Muslims to be fully included in society, to not only improve their own lives, but to locate organised and legitimate avenues to contribute to the building and empowerment of the community in which they live. Accordingly, the phenomenological interviews with the actors in this study clearly demonstrate that Australian MCSOs are full agents in the social inclusion process, providing the vital education, training, employment, voluntary, networking and advocacy opportunities and initiatives for their clients, members and others in the community.

Additionally, these organisations can also help facilitate a better understanding of a model of citizenship which is more inclusive. As Lister (2002) urges "an inclusive model will also be internationalist and multilayered, taking on board notions of global citizenship and its associated responsibilities" (p. 45). This comment is significant as Australian MCSOs continue to navigate the impact of the overseas events (such as 9/11, the Bali bombing, and the violence of ISIS) as well as assist Australian Muslims negotiate their identity in the multicultural, religiously pluralistic Australian society.

\section{References}

Ali, R., Jamoul, L., \& Vali, Y. (2012). A new covenant of virtue: Islam and community organising. London, England: Citizens UK.

Amath, N. (2014). The phenomenology of community activism: Muslim civil society organisations in Australia. Unpublished PhD thesis: Griffith University.

Bollard, M. (2009). A review and critique. In M. Bollard (Ed.), Intellectual disability and social inclusion: A critical review (pp. 5-18). London, England: Elsevier Limited.

Bourdieu, P. (1983). Forms of capital. In J. C. Richards (Ed.), Handbook of theory and research for the sociology of education (pp. 241-258). New York, NY: Greenwood Press.

Cobigo, V., Ouellette-Kuntz, H., Lysaght, R., \& Martin, L. (2012). Shifting our conceptualization of social inclusion. Stigma research and action. Retrieved from http://stigmaj.org/article/view/45

Colaizzi, P. F. (1978). Psychological research as the phenomenologist views it. In R. S. Valle \& M. King (Eds.), Existential phenomenological alternatives for psychology (pp. 48-71). New York, NY: Plenum.

Coleman, J. S. (1994). Foundations of social theory. Cambridge, MA: Harvard University Press. 
Commonwealth of Australia. (2010). Social inclusion unit - overview. Retrieved from http://www.socialinclusion.gov.au/Pages/Overview.aspx

Creswell, J. W. (2007). Qualitative inquiry and research design: Choosing among five approaches $\left(2^{\text {nd }}\right.$ ed.). Thousand Oaks, CA: Sage.

Department of Foreign Affairs and Trade. (2008). Engaging with Australia's Muslim communities. Retrieved from http: www.dfat.gov.au/facts/engaging with muslim community.html

Department of the Prime Minister and Cabinet. (2010). Annual report 2010-2011. Retrieved from http://www.dpmc.gov.au/annual reports/201011/pdf/annual report1011.pdf

Field, J. (2003). Social capital. London, England: Routledge.

Furbey, R. (2007). Faith, social capital and social cohesion. In V. Jochum, B. Pratten, \& K. Wilding (Eds.), Faith and voluntary action (pp. 34-38). London, England: National Council for Voluntary Organisations.

Furbey, R., Dinham, A., Farnell, R., Finneron, D., Wilkinson, G., Howarth, C., Hussain, D., \& Palmer, S. (2006). Faith as social capital: connecting or dividing. Bristol, England: The Policy Press.

Fraser, N. (1997). Justice interruptus. New York, NY: Routledge.

Gilchrist, A. (2009). The well-connected community: A networking approach to community development ( $2^{\text {nd }}$ edition). Bristol, England: The Policy Press.

Gillard, J. (2008, April 10). An Australian social inclusion Agenda. Speech presented at ACOSS National Conference. Canberra, Australia: Author. Retrieved from http://mediacentre.dewr.gov.au/NR/exeres/E5BAE96C-678E-4066-842EAA5A660DA438.htm

Giorgi, A. (1997). The theory, practice, and evaluation of the phenomenological method as a qualitative research procedure. Journal of Phenomenological Psychology, 28(2), 235-260.

Hanifan, L. J. (1916). The rural school community center. Annals of the American Academy of Political and Social Science, 67, 130-138.

Harmon, M. M. (1990). Applied phenomenology and organization. Public Administration Quarterly, 14(1), 10-17.

Hassan, R. (2010). Socio-economic marginalization of Muslims in contemporary Australia: Implications for social inclusion. Journal of Muslim Minority Affairs, 30(4), 575-584.

Hayes, A., Gray, M., \& Edwards, B. (2008). Social inclusion: Origins, concepts and key themes. Canberra, Australia: Australian Government. Retrieved from http://homelessness.energetica.com.au/dmdocuments/aifssocialinclusionrepor toct2009.pd

Human Rights and Equal Opportunities Commission (HREOC). (2004). Isma project . Canberra: Australian Government Publishing Service.

Humphrey, M. (2010). Securitisation, social inclusion and Muslims in Australia. In S. Yasmeen (Ed.), Muslims in Australia: The dynamics of exclusion and inclusion (pp. 56-78). Carlton, Australia: Melbourne University Press.

Husserl, E. (1970b). The crisis of European sciences and transcendental phenomenology (D. Carr, Trans.). Evanston, IL: Northwestern University Press.

Husserl, E. (1980). Phenomenology and the foundations of the sciences. (T. E. Klein \& W. E. Pohl, Trans). The Hague, the Netherlands: Martinus Nijhoff. 
Husserl, E. (2001). Analyses concerning passing passive and active synthesis: Lectures on transcendental logic (A. J. Steinbeck, Trans.). New York, NY: Humanities Press.

Jochum, V., Pratten, B., \& Wilding, K. (2005). Civil renewal and active citizenship: A guide to the debates. London, England: National Council for Voluntary Organisations.

Kabir, N (2008). The identity and self-image of Australian Muslim youth. Paper presented at the conference on the challenges and opportunities of Islam in the West: The case of Australia, Brisbane Convention Centre, South Bank, Queensland, 3-5 March. Retrieved from http://www.griffith.edu.au/ data/assets/pdf file/0019/58312/Kabir.pdf

Levitas, R. (1998). The inclusive society? Social exclusion and new labour. Basingstoke, England: Macmillan.

Lister, R. (2002). Strategies for social inclusion: Promoting social cohesion or social justice. In P. Askonas \& A. Stewart (Eds.), Social inclusion: Possibilities and tensions (pp. 37-54). London, England: Macmillan Press Ltd.

Mansouri, F., \& Lobo, M. (2011). . Introduction: Social inclusion - exploring the concept. In F. Mansouri \& M. Lobo (Eds.), Migration, citizenship and intercultural relations: Looking through the lens of social inclusion (pp. 1-12). Farnham, England: Ashgate.

Moustakas, C. (1994). Phenomenological research methods. Thousand Oaks, CA: Sage Publications.

Noble, G., \& Poynting, S. (2010). White lines: The intercultural politics of everyday movement in social spaces. Journal of Intercultural Studies, 31(5), 489-505.

Poynting, S., \& Mason, V. (2008). The new integrationism, the state and Islamophobia: retreat from multiculturalism in Australia. International Journal of Law. Crime and Justice, 36(4), 230-246.

Putnam, R. D. (2000). Bowling alone: The collapse and revival of American community. New York, NY: Simon and Schuster.

Seidman, I. (2006). Interviewing as qualitative research: A guide for researchers in education and social sciences. New York, NY: Teachers College Press.

Smith, M. K. (2009). Social capital. The encyclopedia of informal education. Retrieved from www.infed.org/biblio/social capital.htm

Taket, A., Crisp, B, Nevill, A., Lamaro, G., Graham, M., \& Barter-Godfrey, S. (2009). Introduction in A. Taket, B. Crisp, A. Nevill, G. Lamaro, M. Graham, \& S. Barter-Godfrey (Eds.), Theorising social exclusion (pp.1-11). Abingdon, England and New York, NY: Routledge.

United Nations. (2014). UN and civil society. Retrieved from http://www.un.org/en/civilsociety/

Van Manen, M. (1990). Researching lived experience: Human science for an action sensitive pedagogy. Ontario, Canada: The University of Western Ontario.

Vertigans, S. (2010). British Muslims and the UK government's 'war on terror' within: Evidence of a clash of civilisations or emergent de-civilising processes? The British Journal of Sociology, 61(1), 26-44.

Wilson, L. (2006). Measurement of social inclusion and social capital. Social Indicators Research, 75(3), 335-360.

Wojnar, D. M., \& Swanson, K. M. (2007). Phenomenology: An exploration. Journal of Holistic Nursing, 25(3), 172-180.

Woolcock, M. (2001). The place of social capital in understanding social and economic outcomes. Isuma: Canadian Journal of Policy Research, 2(1), 1-17. 
Yasmeen, S. (2008). Understanding Muslim identities: From perceived relative exclusion to inclusion. Canberra, Australia: DIAC.

Yasmeen, S. (2010). Understanding the exclusion/inclusion dynamics: Relevance for Muslims in Australia in S Yasmeen (Ed.), Muslims in Australia, inclusion and exclusion (pp. 11-29). Carlton, Victoria: Melbourne University Press.

\section{Biographical notes}

Dr Nora Amath completed her PhD at Griffith University, looking at how Muslim civil society organisations have responded to the sociopolitical context in Australia. Nora's academic interest includes Muslims in the West, the sociology of Islam and community development. She is also highly active in human rights advocacy and community work, including interfaith understanding, and has received numerous awards for her efforts. 